\title{
Impact of Helminth Infections on Production of Chickens
}

\author{
Anders Permin* \\ Vaerloese Dyreklinik, Kirke Vaerloesevej 26, 3500 Vaerloese, Denmark \\ *Corresponding author: Anders Permin, Vaerloese Dyreklinik, KirkeVaerloesevej 26, 3500 Vaerloese, Denmark
}

\begin{tabular}{|c|c|}
\hline ARTICLE INFO & ABSTRACT \\
\hline $\begin{array}{l}\text { Citation: Anders Permin. Impact of Hel- } \\
\text { minth Infections on Production of Chick- } \\
\text { ens. Biomed J Sci \& Tech Res 29(3)-2020. } \\
\text { BJSTR. MS.ID.004819. } \\
\text { Keywords: Free-Range Chickens; Helminth } \\
\text { Infections; Weight Gain; Point of Lay; Egg } \\
\text { Production; Economic Calculations }\end{array}$ & $\begin{array}{l}\text { In free-range poultry rearing systems parasitic infections are frequent with } \\
\text { prevalence's up to } 100 \% \text {, which might reduce productivity. Two hundred and seventy } \\
\text { 3-week-old chicks of Rhode Island Red (RIR), Fayoumi and Sonali (a cross of male RIR } \\
\text { and female Fayouimi) were divided into } 6 \text { groups ( } 2 \text { groups for each breed) consisting } \\
\text { of } 45 \text { chicks. One group of each breed of chickens was given a routine treatment with } \\
\text { levamisole hydrochloride (Poulnec } 囚 \text { ). All chicks were vaccinated against Newcastle } \\
\text { disease, Infectious bronchitis, Infectious bursal disease, Fowl pox, and Fowl cholera. } \\
\text { Feed and water were provided ad libitum. Furthermore, all groups had access to an open } \\
\text { pen. Naturally, infected seeders hens were then used to induce parasitic infections in all } \\
\text { experimental chickens. The non-treated chickens had a significantly higher worm burden } \\
\text { compared to the treated chickens. All non-treated chickens showed a significantly lower } \\
\text { weight gain compared with the treated chickens at the end of experiment. The average } \\
\text { age of point of lay was delayed in the non-treated groups compared to treated groups } \\
\text { and in case of Sonali non-treated group it was significantly higher compared to treated } \\
\text { group. The average number of eggs and the average egg weight were significantly higher } \\
\text { in the treated groups compared to non-treated groups. Economic calculations show that } \\
\text { the treatment of hens against parasitic infections in free-range chickens increases the } \\
\text { net profit pr hen significantly. }\end{array}$ \\
\hline
\end{tabular}

\section{Introduction}

Chickens are major source of dietary protein supply all over the world. This has been clearly demonstrated by the fact that during the last three decades, egg production has doubled and poultry meat production has trebled Anon [1] and it is expected that the poultry production will continue to increase FAO [2]. Egg production has been one of the fastest growing agricultural commodities over the past fifty years with production increasing by $350 \%$. FAO data shows that the global layer flock has increased by $248.3 \%$ to 6.8 billion birds over that time period FAO [2]. Recent trends in commercial poultry production has moved layer hens from in-door production systems to production systems with access to out-door pens LF [3]. In poultry with access to out-door pens, a number of helminth species are widely distributed Ssenyonga, et al. [4-10]. It is assumed that helminths constitute a health problem and low productivity, but there are no exact reports on this issue.
A study made by $\mathrm{He}$ [11] showed that the average weight of helminth infected chickens was significantly lower compared to non-infected flocks. Ascaridia galli infections in chickens cause reductions in growth rate, decreased egg production, and increased mortality Ackert et al, [12-18]. Therefore, the aim of the present research was to investigate the impact of helminthosis on production of chickens.

\section{Materials and Methods}

\section{Animals}

Experimental animals comprised three groups of chickens, namely Rhode Island Red (RIR), Fayoumi, and Sonali (a cross of male RIR and female Fayoumi). One hundred and ten one-day-old chicks of each group were purchased from a commercial farm at 
Rangpur, Bangladesh. The chicks were reared for 3 weeks in a parasite free environment before transfer to the experimental area. To introduce helminth infections in the experimental chickens 44 adult Star Cross hens were collected from a nearby poultry farm. These seeders hens were vaccinated against Newcastle disease, Infectious bronchitis, Infectious bursal disease, Fowl pox and Fowl cholera but no anthelmintic treatments were given. Eight hens were randomly selected and slaughtered for postmortem examination to assess the level of helminth infection in the flock. The remaining thirty-six hens were then grouped into three equal gradations according to EPG count, where the number of Ascaridia galli eggs was used as a criterion for grading. Each of these three groups was mixed with each breed.

\section{Experimental Set-Up}

A poultry house with free-range area was used for the investigation. One month before the set-up of the experiment, the house and the free-range area were thoroughly cleaned with disinfectants. The house was divided into eight equal rooms of $7 \mathrm{mX10m}$, and the free-range area in connection with each room was $10 \mathrm{mX} 20 \mathrm{~m}$. Internally the rooms were separated by a permanent iron grill, and the outside area was fenced by a $2.5 \mathrm{~m}$ high wire netting. The investigation was conducted at the Bangladesh Agricultural University Poultry Farm in Mymensingh, Bangladesh starting from 25th $\mathrm{Au}-$ gust 2001 and terminated on 15th April 2002, totaling 234 days. Ninety 3-week-old chicks from each breed were divided into two groups, where the number of male and female in each group was equal. The chicks were vaccinated against the common diseases e.g. Newcastle disease, Infectious bronchitis, Infectious bursal disease, Fowl pox and Fowl cholera, and one group from each breed was given routine treatment with anthelmintic (Table 1). Both treated and non-treated groups of the same breed of chickens were kept together in the same room up to 100 days (at point of lay) and were allowed to scavenge in the same ground.

Table 1: Schedule for vaccines, anthelmintics, feed and coccidiostat used.

\begin{tabular}{|c|c|c|c|c|}
\hline \multicolumn{2}{|c|}{ Applied items } & \multicolumn{3}{|c|}{ Age of application } \\
\hline Vaccines & Day & Week & Week Method & Manufacturer \\
\hline 1. $\mathrm{ND}+\mathrm{IB}$ & 3rd day of age & & Eye drop & $\begin{array}{c}\text { Intervet International, } \\
\text { Holland }\end{array}$ \\
\hline 2. D 78 & & 2nd week & Eye drop & Do \\
\hline 3. D 78 & & 3rd week & Eye drop & Do \\
\hline 4. ND & 24th day of age & & Eye drop & Do \\
\hline 5. FP & & 5th week & Wing stab & Do \\
\hline 6. ND & 62 nd day of age & & Intramuscularly & Do \\
\hline 7. FC & 81st day of age & & Subcutaneous & DLS, Bangladesh \\
\hline Anthelmintic & 1st dose & Interval & Manufacturer & \\
\hline $\begin{array}{c}\text { Levamisole } \\
\text { Hydrochloride }\end{array}$ & 3rd week of age & 1 month & \multicolumn{2}{|c|}{ Novartis International, Holland } \\
\hline Feed & From & To & Protein \% & Manufacturer \\
\hline 1.Starters* & Day 1 & 10 week & $19 \%$ & $\begin{array}{l}\text { Aftab Multidisciplinary } \\
\text { Farm Ltd. }\end{array}$ \\
\hline 2. Growers* & 11 week & 16 week & $15.15 \%$ & Do \\
\hline 3. Layers & 17 week & End & $17.50 \%$ & Do \\
\hline
\end{tabular}

Note: Vaccines: ND = Newcastle disease, IB = Infectious bronchitis, D 78 = Infectious bursal disease, FP = Fowl pox, FC = Fowl cholera *Starters and Growers were in mesh form and contained Maduramycin 1\% (Coccodiostat) and Layers feed was in pellet form.

After that, the room and the free- range area for each breed, was dived into two equal halves by wire netting partition in order to record the eggs produced by each group. And at the age of point of lay adult seeder hens were removed as because they were in laying condition. All external factors, including the environment, management and ad libitum access to feed and water, were equal for all 6 groups. Commercial starter feed (0-10 week) with $19 \%$ protein, growers ration (11-16 week) with $15.15 \%$, and layers ration (17 weeks to end) with $17.5 \%$ protein were fed to the chickens. Both the starter and growers ration contained Maduramycine 1\% (Coccidiostat) at a dose rate of $0.5 \mathrm{~kg}$ per ton feed. Inside the room saw- dust was used as litter.

\section{Clinical Observations and Recordings}

All groups of chickens were observed on a daily basis for detection of clinical signs, mortality, or any other abnormality. The birds were weighed every fortnight with an electronic balance with a precision of $\pm 2 \mathrm{~g}$. Eggs were collected twice a day, and the number of eggs for each group of birds was recorded on a daily basis. The weight of the individual eggs was also recorded by using an electronic balance with a precision of $\pm 0.5 \mathrm{~g}$. Feed consumption was also measured on a daily basis. 


\section{Parasitological Examination}

At the end of the experiment all birds were sacrificed by cervical dislocation and examined according to Permin [19]. The whole gastrointestinal tract was removed, placed in a tray, opened with pair of scissors in a longitudinal section from the crop to the cloaca, and washed out into a sieve with a mesh aperture of $90 \mu \mathrm{m}$. The larger helminths were picked up from the sieve with forceps, and the sieve retentate was examined under a stereomicroscope to collect smaller worms. The keratinized layer of the gizzard was removed for detecting the presence of Acuaria hamulosa. All helminths were isolated, identified, and counted as described by Permin [20]. Capillaria spp. and Heterakis spp. were identified up to the genera, and all the cestodes were counted under the genus Raillietina, which comprised R. tetragona, R. echinobothrida, Skrajabina cesticillus, Choanotaenia infundibulum, and Hymenolepis spp.

\section{Economical Calculation}

In order to perform economical calculation total expenditure was subtracted from total income. Total expenditure was determined by calculating price of the chicks, price of the total feed consumed, vaccination cost, price of vitamin premix, and price of anthelmintic for each group. On the other hand, total income was determined by calculating selling price of the live birds at the end of the experiment and selling price of the total eggs produced during 7 production weeks.

\section{Statistical Analysis}

The software programme Microsoft Excel, (2000), and the statistical software package Prism (Analytical software, 2000) were used for data storage and data analysis. Column statistic, chi-square test, t-test (parametric or nonparametric) and parametric or nonparametric one-way analysis of variance were used to analyze the data.

\section{Results}

\section{Helminth Infection in Seeder Animals}

The seeder hens were infected with two or more helminth species with a range of 2 to 7 . Four nematode and five cestode species were isolated but no trematode was recorded. The species included: Acuaria hamulosa, Capillaria spp., Ascaridia galli, Heterakis spp., Raillietina tetragona, Raillietina echinobothrida, Skrajabinia cesticillus, Choanotaenia infundibulum and Hymenolepis spp. The average EPG count was 785 with a range of 66 to 2466.

\section{Clinical Observations}

No chickens died during the study and no specific disease symptoms were recorded during the experimental period. However, some birds in the non-treated groups became emaciated and weak.

\section{Body Weight Gain}

In spite of some major differences in the weight of individual birds both in treated and non-treated groups, the average weight gain of the treated groups in all the three breeds of chickens was significantly higher $(\mathrm{P}<0.05)$ at every fortnightly control up to the 4 th fortnight. After that, the differences in weight gain were highly significant $(\mathrm{P}<0.01)$ (Figure 1$) .0 \mathrm{n}$ an average the non-treated groups of RIR, Fayoumi and Sonali showed 20.62, 18.01 and 13.38 $\%$ less body weight gain respectively compared with the treated groups. The mean, standard deviation, Mann-Whitney P-value, and mean differences are shown in (Table 2).

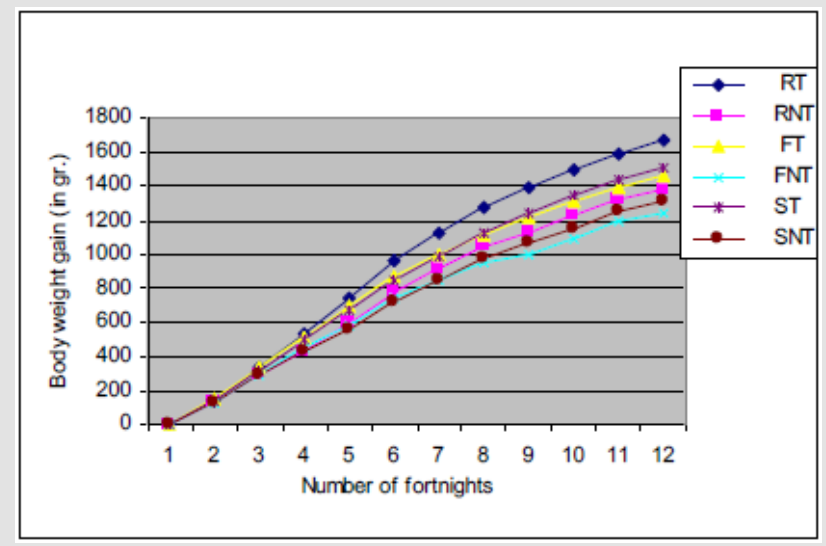

Figure 1: Body weight gain throughout the experimental period.

Note: RT = RIR treated, RNT = RIR non-treated, FT = Fayoumi treated, FNT = Fayoumi non-treated, ST = Sonali treated and $\mathrm{SNT}=$ Sonali non-treated groups of chickens.

\section{Egg Production}

The age of first laying in RIR treated and non-treated group was 156 and 158 days respectively; in Fayoumi it was 156, 159 and in
Sonali it was147, 153 days, respectively. The average age of point of lay was delayed in the non-treated groups compared to treated groups. In the treated and non-treated groups of RIR and Fayoumi 
breeds there was no significant difference between the average age of point of lay, but the average age of point of lay in Sonali non-treated group was significantly higher $(\mathrm{P}<0.05)$ compared with Sonali treated group (Figures $2 \& 3$ ). In order to determine the average percentage of egg production, a total of 7-production weeks from the point of lay were observed. The average percentage of egg production in Fayoumi treated group of chickens was significantly higher $(\mathrm{P}<0.05)$ compared with the non-treated group. But in the
RIR and Sonali treated groups, the differences were highly significant $(\mathrm{P}<0.01)$ compared with the non-treated groups (Table 3$)$. The egg production in non-treated groups of RIR, Fayoumi and Sonali hens was $12.25,7.67$, and $12.76 \%$ less compared with the treated groups. The average egg weight of the treated groups was significantly higher $(\mathrm{P}<0.0001)$ compared with the non-treated groups for all breeds of chickens (Table 3). The mean percentage of egg production and the mean egg weight are also shown in (Table 3).

Table 2: Differences in weight gain at the end of the experiment in different groups of chickens.

\begin{tabular}{|c|c|c|c|}
\hline Groups & Mean \pm SD & P - value* & Mean differences* \\
\hline RT & $1667 \pm 327.4$ & P $<0.0001$ & 284.6 \\
RNT & $1382 \pm 259.0$ & P $<0.0001$ & 222.8 \\
\hline FT & $1461 \pm 275.7$ & P & \\
FNT & $1238 \pm 211.0$ & $1515 \pm 244.8$ & 20001 \\
ST & $1313 \pm 201.6$ & & \\
\hline
\end{tabular}

Note: *P-value and the mean differences are the result of comparison between treated and non-treated in each breed of chicken. RT = RIR treated, RNT = RIR non-treated, FT = Fayoumi treated, FNT = Fayoumi non- treated, $\mathrm{ST}=$ Sonali treated and SNT $=$ Sonali non-treated group of chickens.

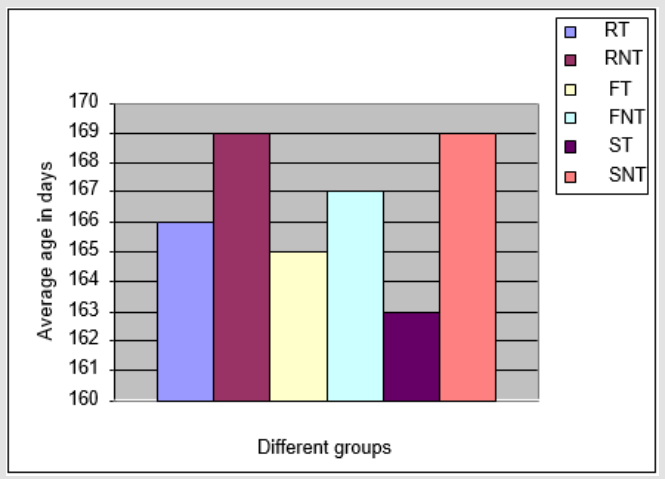

Figure 2: Average age of point of lay in different groups of chickens.

Note: $\mathrm{RT}=\mathrm{RIR}$ treated, RNT = RIR non-treated, FT = Fayoumi treated, FNT = Fayoumi non-treated, ST = Sonali treated and $\mathrm{SNT}=$ Sonali non-treated groups of chickens .

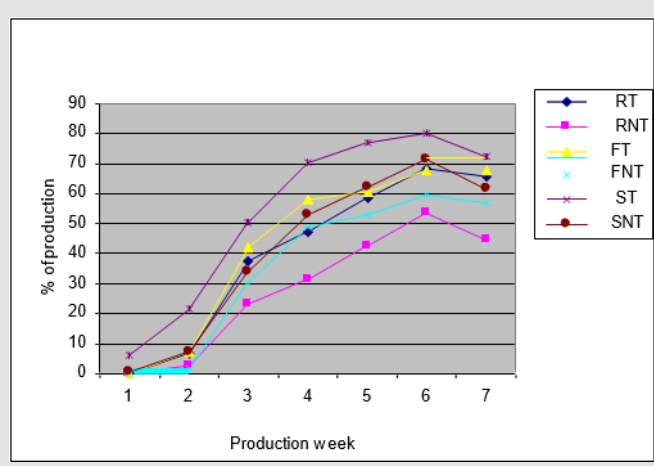

Figure 3: Average percentage of weekly egg production in different groups of chickens.

Note: $\mathrm{RT}=$ RIR treated, RNT $=$ RIR non-treated, FT = Fayoumi treated, FNT $=$ Fayoumi non-treated, ST = Sonali treated and $\mathrm{SNT}=$ Sonali non-treated groups of chickens. 
Table 3: Comparison in average egg production and average egg weight in different groups of chickens throughout the experimental period.

\begin{tabular}{|c|c|c|c|c|}
\hline \multirow{2}{*}{ Groups } & \multicolumn{2}{|c|}{ Average $\%$ of egg production } & \multicolumn{2}{|c|}{ Average egg weight } \\
\hline & Mean \pm SD & P - value* & Mean \pm SD (gm) & $P$ - value* \\
\hline $\mathrm{RT}$ & $40.54 \pm 26.25$ & \multirow{2}{*}{0.0045} & $47.0 \pm 4.8$ & \multirow{2}{*}{$\mathrm{P}<0.0001$} \\
\hline RNT & $28.29 \pm 20.23$ & & $40.8 \pm 4.2$ & \\
\hline FT & $43.49 \pm 27.47$ & \multirow{2}{*}{0.0249} & $39.8 \pm 4.1$ & \multirow{2}{*}{$\mathrm{P}<0.0001$} \\
\hline FNT & $35.82 \pm 24.75$ & & $36.6 \pm 3.0$ & \\
\hline ST & $54.14 \pm 28.45$ & \multirow{2}{*}{0.0039} & $44.7 \pm 4.5$ & \multirow{2}{*}{$\mathrm{P}<0.0001$} \\
\hline SNT & $41.33 \pm 27.33$ & & $40.6 \pm 3.5$ & \\
\hline
\end{tabular}

Note: *P - value is calculated between treated and non-treated groups in the same breed. RT $=$ RIR treated, RNT $=$ RIR non-treated, FT = Fayoumi treated, FNT = Fayoumi non-treated, ST $=$ Sonali treated and SNT $=$ Sonali non-treated groups of chickens .

\section{Parasitological Findings and Feed Consumption}

The average worm burdens of all the non-treated groups were significantly higher $(\mathrm{P}<0.05)$ compared with the treated groups of chickens. The overall efficacy of levamisole hydrochloride, at a dose rate pf $20 \mathrm{mg}$ per kg body weight, was very good ranging from $84 \%$ to $100 \%$, but the average efficacy against Capillaria spp. was the highest, and it was significantly higher $(\mathrm{P}<0.05)$ compared to the average efficacy against other helminths. No significant difference

Table 4: Worm burdens at slaughter (at the end of the experiment). was observed among the efficacy against other helminths. Average worm burdens among the groups, average efficacy of levamisole hydrochloride, and P-value of the average efficacy against Capillaria spp. versus the efficacy against other helminths are shown in (Table 4). There was no significant difference between treated and non-treated groups regarding feed consumption. The P- value between treated and non-treated groups of RIR, Fayoumi, and Sonali were $0.896,0.294$, and 0.694 , respectively.

\begin{tabular}{|c|c|c|c|c|c|c|c|c|}
\hline \multirow{2}{*}{ Helminths } & \multicolumn{6}{|c|}{ Average worm burden } & \multirow{2}{*}{$\begin{array}{l}\text { Average } \\
\text { efficacy }\end{array}$} & \multirow{2}{*}{ P-value } \\
\hline & RT & RNT & FT & FNT & ST & SNT & & \\
\hline Capillaria spp & 0.51 & 25.29 & 0 & 23.78 & 0 & 14.69 & $99 \%$ & $*$ \\
\hline A. hamulosa & 0.09 & 0.91 & 0 & 0.69 & 0.11 & 0.82 & $92 \%$ & 0.017 \\
\hline A. galli & 1.09 & 11.93 & 1.58 & 11.53 & 2.18 & 10.42 & $85 \%$ & 0.0003 \\
\hline Heterakis spp. & 9.69 & 151.13 & 7.64 & 111.13 & 12.29 & 131.67 & $92 \%$ & 0.017 \\
\hline $\begin{array}{l}\text { Raillietina } \\
\text { spp. }\end{array}$ & 2.87 & 12.44 & 1.44 & 10.56 & 0.91 & 9.09 & $84 \%$ & 0.0001 \\
\hline
\end{tabular}

Note: *P-value is calculated between the average efficacy of Livamisol hydrochloride against Capillaria spp. versus the average efficacy against other helminths recorded; RT = RIR -treated, RNT = RIR non-treated, FT = Fayoumi treated, FNT = Fayoumi non-treated, ST $=$ Sonali treated and SNT = Sonali non-treated groups of chickens.

\section{Economic Calculation}

The net profit for all treated groups were higher compared to non-treated groups. Furthermore, the net profit for Sonali treated group is higher compared to that of any other group (Table 5). The total feed consumption, average body weight at the end of the experiment, and total egg production during the observation period are shown in (Table 6).

Table 5: Comparison in feed consumption, total body weight gain and egg productions among the different groups of chickens.

\begin{tabular}{|c|c|c|c|c|c|c|c|}
\hline Groups & $\begin{array}{l}\text { Number } \\
\text { of birds }\end{array}$ & $\begin{array}{l}\text { Total feed } \\
\text { consumption } \\
\text { for whole } \\
\text { period }(\mathrm{kg})\end{array}$ & 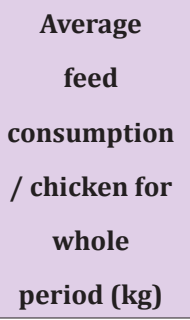 & $\begin{array}{c}\text { Average } \\
\text { weight } \\
\text { gain at the } \\
\text { end of } \\
\text { experiment } \\
\text { (kg) }\end{array}$ & $\begin{array}{c}\text { Per day } \\
\text { average } \\
\text { egg } \\
\text { production }\end{array}$ & $\begin{array}{c}\text { Average } \\
\text { \% of } \\
\text { hens in } \\
\text { lay }\end{array}$ & $\begin{array}{c}\text { Total egg } \\
\text { production } \\
\text { for whole } \\
\text { period }\end{array}$ \\
\hline RT & 45 & 558.23 & 12.405 & 1.841 & 18.24 & 40.54 & 894 \\
\hline RNT & 45 & 557.19 & 12.382 & 1.554 & 12.73 & 28.29 & 624 \\
\hline
\end{tabular}




\begin{tabular}{|c|c|c|c|c|c|c|c|}
\hline FT & 45 & 463.05 & 10.29 & 1.631 & 19.57 & 43.49 & 959 \\
\hline FNT & 45 & 454.64 & 10.103 & 1.404 & 16.12 & 35.82 & 790 \\
\hline ST & 45 & 497.34 & 11.052 & 1.682 & 24.36 & 54.14 & 1194 \\
\hline SNT & 45 & 493.7 & 10.971 & 1.488 & 18.62 & 41.38 & 912 \\
\hline
\end{tabular}

Table 6: Economic calculation showing differences in the net profit among different groups of chickens.

\begin{tabular}{|c|c|c|c|c|c|c|}
\hline \multicolumn{7}{|c|}{ Groups } \\
\hline Items & RT & RNT & FT & FNT & ST & SNT \\
\hline \multicolumn{7}{|l|}{ Expenditure } \\
\hline 1. Price of 45 chicks @ $0.14 \$$ per chick & 6.3 & 6.3 & 6.3 & 6.3 & 6.3 & 6.3 \\
\hline 2. Price of feed consumed @ 0.21 \$ per kg & 117.23 & 117 & 97.24 & 95.47 & 104.44 & 103.68 \\
\hline 3. Vaccination cost @ 0.12 \$ per chick & 5.4 & 5.4 & 5.4 & 5.4 & 5.4 & 5.4 \\
\hline 4. Price of vitamin premix @ $0.06 \$$ per chick & 2.7 & 2.7 & 2.7 & 2.7 & 2.7 & 2.7 \\
\hline 5. Price of anthelmintic @ 0.02 \$ per chick & 0.9 & - & 0.9 & - & 0.9 & - \\
\hline Total & 132.53 & 131.4 & 112.54 & 109.87 & 119.74 & 118.08 \\
\hline \multicolumn{7}{|l|}{ Income } \\
\hline $\begin{array}{l}\text { 1. Selling price of birds @ } 1.58 \text { \$ per kg live } \\
\text { weight }\end{array}$ & 130.9 & 110.49 & 115.97 & 99.82 & 119.59 & 105.8 \\
\hline 2. Selling price of eggs & $53.64^{1}$ & $31.20^{2}$ & $57.54^{1}$ & $39.50^{2}$ & $71.64^{1}$ & $45.60^{2}$ \\
\hline Total & 184.54 & 141.69 & 173.51 & 139.32 & 191.23 & 151.4 \\
\hline Net Profit (\$) & 52.01 & 10.29 & 60.97 & 29.45 & 71.49 & 33.32 \\
\hline
\end{tabular}

Note: 1 the price of the egg is @ 0.06 \$ per egg; 2 the price of the egg is @ 0.05 \$ per egg,

\section{Discussion}

Helminths might cause death of chickens Ikeme, et al. [15,17], but in the present investigation no death was recorded. The possible explanation may be that feed was supplied ad libitum with adequate vitamin premix supplementation since nutritional deficiency aggravates the detrimental effects of helminth infections Ackert [12]. The fact that some of the non-treated groups of chickens became emaciated and debilitated is consistent with the findings of Ackert, et al. $[12,13,15]$. The significantly lower $(\mathrm{P}<0.05)$ average worm burdens in all treated groups compared with the non-treated groups indicates that efficacy of levamisole hydrochloride is very good at a dose rate of $20 \mathrm{mg}$ per $\mathrm{kg}$ body weight. The efficacy of levamisole hydrochloride against $A$. galli infection as recorded in the present study is slightly lower than the findings of Verma, et al. [21, 22] reported $91.8 \%$ and $95 \%$ efficacy of levamisole hydrochloride against immature and mature A. galli respectively, in chickens, and Cruthers [22] found $100 \%$ efficacy with levamisole hydrochloride against mature A. galli.

The difference might be due to dose variation or to mixed infection in the present study. Furthermore, it is possible that the continuous use of the drug may have led to development of a degree of resistance in the helminths against levamisole hydrochloride. The average slightly greater weight loss in the RIR non-treated chickens infected with helminths, and slightly lower weight loss in the Fayoumi and Sonali, compared with the findings of He [11], in which the authors used the local chickens for their study, clearly demonstrates the difference of effects of infections with helminths between different breeds. But the effects of individual groups of helminths on weight gain, as recorded in this study, were highly consistent with the observations by He, [11]. The authors also found that the mixed infections cause higher weight loss than single parasite class infections. The weight loss due to helminth infections is also supported by the findings of other researchers: weight loss due to the nematode Ascaridia galli was reported by Ackert, et al. [12-15,23,24,16-19] and the weight loss due to coccidial parasites in chickens was reported by Mathis, et al. [25-27].

There are also some reports that helminths might cause severe weight loss in sheep, cattle, and swine Sinclair, et al. [28-36]. Age of point of lay differs from some of the previous reports. The age (157, 157.5, and 150 days for RIR, Fayoumi, and Sonali, respectively) at point of lay in the present study was much lower compared with the report of Barua [37] who reported the age at sexual maturity (age at first egg laid) as 262.5, 238.5, and 247.5 days in RIR, Fayoumi, and Fayoumi X RIR respectively. Similarly, Rahman [38] reported age of first egg at 231 days in Sonali (RIR X Fayoumi); and Kicka [39] found the age at sexual maturity of Fayoumi and White Baladi 229 and 261 days, respectively. The variation in attaining sexual maturity might be due to the fact that all the previous studies were performed at free-range and without feed supplementation. Barua [37] also reported that in the free-range extra feed supplementation decreases the age of sexual maturity. However, the age of sexual maturity of Fayoumi breed, as recorded in the present study, was somewhat closer to the findings of Stino, et al. $[40,41]$ who reported that the age of sexual maturity of Fayoumi hens ranged from 177 to 181 and 162 to 215 days respectively? 
The observations that there was no significant difference in the average age of point of lay between the treated and non-treated groups of RIR and Fayoumi, indicates the absence of any effect of helminths infection in attaining puberty of these birds, at least up to the level of parasitic burden recorded in this study. But the significant difference $(\mathrm{P}<0.05)$ in the average age of point of lay in Sonali treated group as compared with the Sonali non-treated group, suggests that helminth infections can delay the onset of egg laying in these chickens. The fact that the Sonali chickens have the highest percentage of egg production among the breeds is consistent with the findings of Rahman [38]. The relatively higher average percentage of egg production of Fayoumi breed compared to RIR is supported by the observation of Barua [37]. Asiedu, [42] reported that in average the crossbreds produced more eggs. The significantly higher $(\mathrm{P}<0.05$ for Fayoumi and $\mathrm{P}<0.01$ for others) average egg production in the treated groups of chickens compared with the non-treated groups is easily understandable and is in agreement with Cram, et al. [43-45]; in which the authors reported a decrease in egg production in chickens infected with A. galli.

But Botero [46] observed no effect on egg production in White leghorn hens infected with Raillietina cesticillus. Similarly, Permin [19] observed no effect on egg production in Lohmann brown, and similarly Gauly [47] found no effects on Lohmann white and brown hens infected with A. galli. These differences may possibly be caused by the fact that different breeds were used in these studies, or the reason may be that the authors begin the investigations with 7 to 9-month-old, 17-week-old, and 20- week-old birds respectively, since Ackert [48] reported that at the age of sexual maturity chickens acquire maximum resistance to A. galli infection. The findings that RIR had the highest egg weight compared to that of Fayoumi and Sonali, and that the egg weight of Sonali was in between the parental breeds are in accordance with observations of other investigators Mostageer, et al. [49,50]. The average egg weight of Fayoumi and RIR treated groups is highly consistent with Amer [50], who reported $39.6 \mathrm{~g}$ and 50.1g, respectively. But the average egg weights of RIR, Fayoumi and Sonali, as recorded in this study are higher than the findings of Barua [37], who found 44g, 35g, and 40g, respectively. They argued that the smaller eggs obtained in their study might be due to the nutritional stress in free- range system.

There is no published information on the effect of helminth infections on egg weight in chickens. However, in the present study the significantly higher $(\mathrm{P}<0.0001)$ average egg weight of the treated groups of chickens compared with the non- treated groups in all breeds, clearly demonstrates an effect of helminth infection on egg weight. The fact that there were no significant differences in feed consumptions between treated and non-treated groups, contrary with the findings of Clapham, et al. [51-57]. They reported that the feed intake might be decreased in helminth-infected chickens. The higher net profit for all the treated groups of chickens clearly demonstrates that the use of anthelmintic is economically benefi- cial and the highest profit obtained with the Sonali treated group suggests that in the free-range production system, this cross breed birds are more profitable. Rahman [38] reported in the scavenging system Sonali crossbreed is more suitable. In addition, with the findings of Rahman [38], our findings suggest that regular deworming of the free-range chickens will definitely increase the net profit even to an extent of several times.

\section{Conclusion}

The overall performance of the Sonali crossbreed is found to be good with regard to early sexual maturity, egg production, and comparatively little difference in weight gain between parasited and non-parasited group. The last parameter suggests that there may be some genetic resistance to helminth infections in the Sonali crossbreed. In general, the helminth infected groups of chickens show marked loss in weight gain and decreased egg production and egg weight, suggesting that the helminth infection may play a vital role as a hindrance in the economical rising of the poultry industry.

\section{Acknowledgement}

The financial support of DANIDA, is highly appreciated. We are grateful to the authority of Bangladesh Agricultural University Poultry Farm for providing facilities for conducting the study.

\section{References}

1. Anonymous (2018) WATT poultry statistical yearbook.

2. (1995) Food and Agricultural Organization (FAO) of the United Nations. FAO yearbook 2018. FAO, Rome.

3. LF (2018) Landbrug og Fødevarer. Statistisk Årbog.

4. GSZ Ssenyonga (1982) Prevalence of helminth parasites of domestic fowl (Gallus domesticus) in Uganda. Trop. Anim. Health Prod 14: 201-204.

5. Fatihu MY, Ogbogu VC, Njoku CO, Saror DI (1991) Comparative studies of gastrointestinal helminths of poultry in Zaria, Nigeria. Rev Elv Med Vet Pays Trop 44: 175-177.

6. Pandey VS, Demey F, Verhulst A (1992) Parasitic Diseases: A neglected problem in village poultry in Sub-Saharan Africa. pp. 136-141. In: Pandey VS, Demey F (Eds.). Village poultry production in Africa. Rabat, Morocco.

7. Bagust TJ (1994) Improving health for poultry production in Asia: A development perspective. Avian Pathol 23: 395-404.

8. Permin A (1997) Helminths and helminthosis in poultry with special emphasis on Ascaridia galli in chicken. Ph. D. thesis, KVL. Copenhagen, Denmark.

9. Kaufmann F, Daş G, Sohnrey B, Gauly M (2011) Helminth infections in laying hens kept in organic free-range systems in Germany. Livestock Science 141: 182-187.

10. Katoch R, Yadav A, Godara R, Khajuria JK, Borkataki S, et al. (2012) Prevalence and impact of gastrointestinal helminths on body weight gain in backyard chickens in subtropical and humid zone of Jammu, India J Parasit Dis 36(1): 49-52.

11. He S, Susilowati VEHS, Purwati E, Tiuria R (1990) An estimate of meat production loss in native chicken in Bogor and its surrounding districts due to gastrointestinal helminthiasis.pp. 57. In: Proceedings from the Fifth National Congress of Parasitology. Pandaan, Pasuruan, East Java, June p. 23-25.

12. Ackert JE, Herrick CA (1928) Effects of the nematode Ascaridia lineata (Schneider) on growing chickens. J Parasitol 15: 1-15. 
13. Reid WM, Carmon JL (1958) Effects of number of Ascaridia galli in depressing weight gains in chicks. J Parasitol 44: 183-186.

14. Vegad JL, Kolte GN, Kumar N (1971) Intestinal perforation and peritonitis in ascaridiasis in a white leghorn cockerel. Vet Rec 105(1): 16.

15. Ikeme MM (1971) Weight changes in chickens placed on different levels of nutrition and varying degrees of repeated dosage with Ascaridia galli eggs. Parasitol 63: 251-260.

16. Malviya HC, Dwivedi P, Verma TK (1988) Effect of irradiated Ascaridia galli eggs on growth and cell-mediated immune responses in chickens. Vet. Parasitol 28: 137-141.

17. Ramadan HH, Znada ANY (1991) Some pathological and biochemical studies on experimental ascaridiasis in chickens. Die Nahrung 1: 71-84.

18. Fatihu MY, Ogbogu VC, Njoku CO, Saror DI (1992) Study of the pathogenicity of experimental Ascaridia galli infection in broiler chickens. Bull Anim Prod Afr 40: 19-24.

19. Permin A, Hansen JW (1998) Epidemiology, Diagnosis and control of parasites, Food and Agriculture Organization of the United Nations. Rome, Italy.

20. Permin A, Nansen P, Bisgaard M, Frandsen F (1998) Ascaridia galli infections in free-range layers fed on diets with different protein contents. Br Poult Sci 39: 441-445.

21. Verma N, Bhantnagar PK, Banerjee DP (1991) Comparative efficacy of three broad spectrum anthelmintics against Ascaridia galli in poultry. Indian J Anim Sci 61(8): 834-835.

22. Cruthers LR, Al Khateeb GH, Hansen MF (1975) Efficacy of levamisole (Tramisol) in drinking water against some nematodes of chickens. In: proceedings of the Oklahoma Academy of Science 55: 119-121.

23. Pavlicek J, Dykova I (1975) Experimental infection with Ascaridia galli in young chickens of different age. Acta Vet Brno 44: 223-233.

24. Matta SC, Ahluwalia SS (1980) Studies on effect of Ascaridia galli infection on growth rates of chickens. Indian J Poult Sci 15: 1-4.

25. Mathis GF, Washburn KW, Mc Dougald LR (1984) Genetic variability of resistance to Eimeria acervulina and E. tenella in chickens. Theor Appl Genet 68: 385-389.

26. Bumstead N, Millard B (1987) Genetics of resistance to coccidiosis: Response of inbred chicken lines to infection by Eimeria tenella and Eimeria maxima. Br Poult Sci 28: 705-715.

27. Clare RA, Taylor JR RL (1989) Characterization of resistance and immunity to Eimeria tenella among major histocompatibility complex B-F / B-G recombinant hosts. Poult Sci 68: 639-645.

28. Sinclair KB (1962) Observations on the clinical pathology of ovine fascioliasis. Br Vet J 118: 37-53.

29. Boray JC (1969) Experimental fascioliasis in Australia. Advan Parasitol 7: $96-210$.

30. Horak IG (1971) Paramphistomiasis of domestic ruminants. Advan Parasitol 9: 33-72.

31. Preston JM, Dargie JD, Maclean JM (1973) Pathophysiology of ovine Schistosomiasis 1. A clinicopathological study of experimental Schistosoma mattaheei infections. J Comp Pathol 83: 401-415.

32. Berry CI, Dargie JD (1976) The role of host nutrition on the pathogenesis of ovine fascioliasis. Vet Parasitol 2: 317-332.

33. Hawkins CD, Morris RS (1978) Depression of productivity in sheep infected with Fasciola hepatica. Vet Parasitol 4: 341-351.

34. Saad AM, Hussein MF, Dargie JD, Taylor MG, Nelson GS (1980) Schistosoma bovis in calves: the development and clinical pathology of primary infections. Res Vet Sci 28: 105-111.

35. Hawkins CD (1984) Productivity in sheep treated with diamphenathide at different times after infection with Fasciola hepatica. Vet Parasitol 15 117-123.
36. Bernardo TM, Dohoo IR (1988) Swine Ascariasis: impact on production and abattoir surveillance. Acta. Vet. Scand. Supplement. 84: 265-267.

37. Barua A, Howlider MAR, Yoshimura Y (1998) A study on the performance of Fayoumi, Rhode Island Red and Fayoumi X Rhode Island Red chickens under rural condition of Bangladesh. AJAS 6: 635-641.

38. Rahman M, Sorensen P, Jensen HA, Dolberg F (1997) Exotic hens under semiscavenging conditions in Bangladesh. Livest. Res Rural Dev 9(3): $1-11$.

39. Kicka MAM, Osman MA, Raid SA, Kamar GAR (1979) Relation between yolk cholesterol and some economic characters in chickens. Egypt. J Anim Prod 19: 115.

40. Stino FKR, Gother NE, Kamar GAR, Hanash NA (1983) Effect of breed and housing type on egg production of White Baladi and Fayoumi hens in the subtropics. Egypt. J Anim Prod 23(1-2): 143-150.

41. Kosba MA, Shawer MF, El Ibiary HM (1978) Selection for age at sexual maturity in chickens under different mating systems. Alexandria J Agric Research 6: 154-161

42. Asiedu FHK, Weever W (1993) Growth rate and egg production of Creole and Rhode Island Red X Creole fowls. Trop Anim Hlth Prod 25: 111-117.

43. Cram EB (1928) Nematodes of pathological significance found in some economically important birds in North America, USDA. Tech Bull 49: 1.

44. Costa JO (1970) Effect of experimental Ascaridia galli (Schrank, 1788) inoculation in chickens. Arquivos da Escola de Veterinaria Universidade Federal de Minas Corias 22: 11-31.

45. Matta SC (1981) Effect of Ascaridia galli infection on the egg production in poultry. Indian J Poult Sci 16: 283-284.

46. Botero H, Reid WM (1969) The effects of the tape worm Raillietina cesticillus upon body weight gains of broilers, poults and on egg production. Poult Sci 48(2): 536-542.

47. Gauly M, Bauer C, Preisnger R, Erhardt G (2002) Genetic differences of Ascaridia galli egg output in laying hens following a single dose infection. Vet Parasitol 103(1-2): 99-107.

48. Ackert JE, Dewhirst LW (1950) Resistance of fowls to parasitism affected by female sex hormone. J Parasitol 36(6): 16.

49. Mostageer M, Kamar GAR (1961) On the inheritance of egg weight. Poult Sci 40: 857-860.

50. Amer MF (1965) A comparison of sexual maturity age and egg weight between standard breeds and Fayoumi chickens in subtropics. Poult Sci 44(5): 1180-1184.

51. Clapham PA (1937) On some lesions associated with helminths in birds of economic importance. J. Helminthol 15(1): 49-52.

52. Keymer A, Crompton DWT, Walters DE (1983) Nippostrongylus (Nematoda) in protein- malnourished rats; host mortality, morbidity, and rehabilitation. Parasitol 86(3): 461-475.

53. Crompton DWT (1984) Influence of parasitic infection on food intake. Federation proceedings 43(2): 239-245.

54. Holmes PH, Coop RL (1994) Workshop summary: Pathophysiology of gastrointestinal parasites. Vet Parasitol 54(1-3): 299-303.

55. Anonymous (1998) Annual reports on survey of rural poultry in Bangladesh. Department of Livestock Services, Government of the Peoples of Bangladesh, 1998.

56. Magwisha HB, Kassuku AA, Kyvsgaard NC, Permin A (2002) A comparison of the prevalence and burdens of helminth infections in growers and adult free-range chickens. Trop Anim Health Prod 34(3): 205-214.

57. Permin A, Magwisha H, Kassuku AA, Nansen P, Bisgaard M, et al. (1997) A cross-sectional study of helminths in rural scavenging poultry in Tanzania in relation to seasons and climate. J Helminthol 71(3): 233240. 
ISSN: 2574-1241

DOI: 10.26717/BJSTR.2020.29.004819

Anders Permin. Biomed J Sci \& Tech Res

(C) This work is licensed under Creative

Submission Link: https://biomedres.us/submit-manuscript.php

$\begin{array}{ll}\text { BIOMEDICAL } & \text { Assets of Publishing with us } \\ \text { RESEARCHES } & \text { - Global archiving of articles } \\ & \text { - Immediate, unrestricted online access } \\ & \text { - Rigorous Peer Review Process } \\ & \text { - Anttps://biomedres.us/ }\end{array}$

